\title{
Sikap Guru terhadap Anak Usia Dini dengan Autism Spectrum Disorder
}

\author{
Septiana Arini ${ }^{1 凶}$ Farida Kurniawati ${ }^{2}$ \\ Psikologi Terapan Pendidikan Anak Usia Dini, Universitas Indonesia ${ }^{1}$ \\ Psikologi, Universitas Indonesia ${ }^{2}$ \\ DOI: $10.31004 /$ obsesi.v4i2.410
}

\begin{abstract}
Abstrak
Sikap guru terhadap anak usia dini dengan Autism Spectrum Disorder (ASD) adalah sebuah predisposisi yang dapat ditunjukkan secara favorable atau unfavorable. Sikap ini merupakan faktor penting yang memengaruhi bagaimana kualitas pengajaran terhadap anak dengan ASD di sekolah inklusif. Kajian literatur sistematis ini bertujuan untuk mengetahui sikap guru terhadap anak usia dini dengan ASD dan faktor yang memengaruhi sikap tersebut. Pencarian dilakukan melalui empat mesin pencari elektronik, yaitu Taylor \& Francis Online, ProQuest, EBSCOhost, dan Science Direct . Tahapan identifikasi, screening, uji kelayakan, dan eliminasi dilakukan hingga diperoleh 2 artikel yang sesuai dengan tujuan penelitian. Hasilnya, ditemukan bahwa terdapat perbedaan sikap guru terhadap anak usia dini dengan ASD antara pre-service dan in-service teacher. Pre-service teacher menunjukkan sikap positif sedangkan in-service teacher cenderung netral atau sedikit setuju. Penelitian lebih lanjut disarankan untuk dilakukan terhadap guru-guru PAUD inklusif di Indonesia untuk memperluas gambaran dalam berbagai konteks budaya dan negara, serta memfokuskan penelitian sikap guru yang bukan merupakan dampak hasil pelatihan tertentu.
\end{abstract}

Kata Kunci: sikap guru; anak usia dini; pendidikan inklusif; Autism Spectrum Disorder

\begin{abstract}
Teachers' attitudes towards young children with Autism Spectrum Disorder (ASD) are a predisposition that can be shown favorably or unfavorably. This attitude is an essential factor that affects the quality of teaching towards children with ASD in inclusive schools. This systematic literature study aims to reveal the attitudes of teachers towards young children with ASD and factors affecting that attitudes. Finding through four electronic search engines, namely Taylor \& Francis Online, ProQuest, EBSCOhost, and Science Direct. The process for selecting studies are identification, screening, assessing for eligibility, and elimination, there obtained two articles that fit the research objective. The findings show that there are differences in the attitudes by pre-service and in-service teachers towards young children with ASD. Pre-service teachers showed a positive attitude while in-service teachers tend to be neutral or slightly agree. It is then suggested that (1) further study be conducted towards inclusive early childhood teacher in Indonesia to expand the description in a variety of country and cultural contexts; and (2) the research be focused on teachers' attitudes which are not the outcome of a specific training.
\end{abstract}

Keywords: teacher's attitude; early childhood; inclusive education; Autism Spectrum Disorder

Copyright (c) 2020 Septiana Arini, Farida Kurniawati

$\triangle$ Corresponding author :

Email Address : septiana.arini@gmail.com (Depok, Indonesia )

Received 27 December 2019, Accepted 19 January 2020, Published 20 January 2020 


\section{PENDAHULUAN}

Early childhood merupakan masa yang berada pada rentang usia dua sampai lima tahun (Brooks, 2013). Masa ini terkadang disebut tahun prasekolah dengan rentang pada akhir masa infancy sampai usia lima atau enam tahun (Santrock, 2012). Perkembangan yang cepat terkait kemampuan dan keterampilan anak terjadi pada masa ini, namun beberapa anak menunjukkan tanda-tanda keterlambatan yang jelas sejak lahir (Brooks, 2013). Pada 15 tahun terakhir, terjadi peningkatan jumlah anak yang didiagnosis mengalami Pervasive Developmental Disorders, jumlah paling banyak mengalami autisme dan Asperger (Slade \& Wissow, 2004 dalam Brooks, 2013). Namun Sharma, Gonda, dan Tarazi (2018) menerangkan bahwa dalam Diagnostic and Statistical Manual of Mental Disoreders (DSM-5), autisme tidak lagi berada di bawah naungan Pervasive Developmental Disorder (PDD) melainkan telah menjadi bagian dari kategori yang lebih luas, yaitu Autism Spectrum Disorder (ASD) sehingga dengan revisi ini kriteria diagnostiknya pun berbeda. ASD seringkali sudah bisa dideteksi sejak dini, yaitu pada saat anak mulai berusia satu hingga tiga tahun (Santrock, 2012).

Autisme atau Autism Spectrum Disorder (ASD) adalah "a complex neurodevelopmental disorder characterized by abnormalities in social communication and unusual behaviors and interests" (Mash \& Wolfe, 2016). Autism Spectrum Disorder (ASD) adalah "a complex developmental condition that involves persistent challenges in social interaction, speech and nonverbal communication, and restricted/repetitive behaviors" (Copeland, 2018). Pada intinya, ASD merupakan sebuah gangguan perkembangan yang ditandai dengan masalah komunikasi sosial dan perilaku. Dalam DSM-5 autisme atau Autism Spectrum Disorder (ASD) termasuk dalam klasifikasi neurodevelopmental disorders. Neurodevelopmental disorders (NDDs) adalah kondisi-kondisi pada berbagai aspek sebagai hasil dari perkembangan abnormal pada otak yang ditandai oleh kerusakan-kerusakan pada fungsi kognitif, komunikasi, tingkah laku dan/atau keterampilan motorik (Mullin, Gokhale, Moreno-De-Luca, Sanyal, Waddington, \& Faundez, 2013). Kondisi-kondisi tersebut seringkali kronis dan memengaruhi kemampuan anak dalam belajar atau berfungsi secara normal (Mash \& Wolfe, 2016).

Keterlambatan yang dialami oleh anak dengan ASD, menurut Brooks (2013) menyebabkan orangtua harus memeroleh dan memonitor semua layanan yang efektif dalam memenuhi kebutuhan anak. Hal ini penting dilakukan karena menurut WHO-UNICEF 2012 (Tichá, Abery, Johnstone, Poghosyan, \& Hunt, 2018) pada early childhood inilah waktu yang sangat penting untuk memastikan intervensi apa yang dapat membantu anak-anak yang memiliki disabilitas atau keterlambatan perkembangan mencapai potensi terbaik mereka. Salah satu kebutuhan tersebut adalah memeroleh pendidikan karena pada early childhood anak-anak sudah ada yang mulai masuk prasekolah. Menurut Papalia dan Martorell (2014), masuk prasekolah merupakan langkah penting bagi anak karena mendukung perkembangan anak pada aspek fisik, kognitif, dan lingkungan sosial. Oleh karena itu, orangtua perlu memertimbangkan sekolah yang tepat bagi anak. Salah satu pilihannya adalah prasekolah inklusif.

Pada umumnya, inklusi merupakan sebuah sistem dimana anak dengan dan tanpa kebutuhan khusus berada pada setting yang sama, dalam hal ini kebanyakan pada setting kelas (Odom \& Diamond, 1998 dalam Sucuoğlu, Bakkaloğlu, Karasu, Demir, \& Akalin, 2013). Brown dan Fortain (2011, dalam Ozel Eren, Gumus, Ganesan, Daud, Darusalam, \& Siraj, 2017). Data menunjukkan bahwa inklusi memberikan dampak yang sangat baik bagi anak prasekolah dengan ASD (Stahmer, Akshoomoff, \& Cunningham, 2011). Prasekolah inklusif dan early primary schooling memberikan kesempatan anak untuk belajar, bermain, berpartisipasi, berinteraksi dengan sebaya, dan mengembangkan pertemanan sebagai ruang yang penting bagi anak berkebutuhan khusus untuk dapat berkembang secara optimal (WHO-UNICEF, 2012). Manfaat juga diperoleh oleh anak yang tidak memiliki kebutuhan khusus. 
Pendidikan inklusif memberikan kesempatan bagi anak yang tidak memiliki kebutuhan khusus untuk belajar tentang keberagaman dalam hal karakteristik, talenta, dan temperamen (Fakolade, Adeniyi, \& Tella, 2009). Anak berkebutuhan khusus memiliki kesempatan yang lebih banyak untuk mempraktikkan keterampilan yang baru diperoleh dengan teman sebayanya di kelas inklusif (Lamorey \& Bricker, 1993 dalam Diamond \& Hestenes, 1996). Manfaat sekolah inklusif tidak hanya bagi anak berkebutuhan khusus saja, namun juga bagi anak yang tidak berkebutuhan khusus. Manfaat yang bisa diperoleh adalah anak memiliki kesempatan mengembangkan kognisi sosial (anak lebih peduli akan kebutuhan orang lain), perilaku prososial (anak akan lebih bertanggung jawab terhadap kebutuhan orang lain), dan penerimaan akan keberagaman (Peck, Carlson, \& Helmstetter, 1992 dalam Diamond \& Hestenes, 1996). Anak yang tidak berkebutuhan khusus juga dapat mengembangkan sensitivitas dan sikap yang positif, memiliki kesempatan untuk bekerja sama, serta membentuk interaksi yang positif dengan orang lain yang berbeda dengan mereka (Sucuoğlu et al., 2013).

Pada saat anak dimasukkan ke dalam pendidikan inklusif, maka peranan guru sangat dibutuhkan karena anak menghabiskan berjam-jam waktunya di sekolah dan menjalin hubungan dengan orang dewasa selain orangtua. Hal ini dikarenakan sekolah merupakan salah satu konteks utama dimana anak mulai belajar mandiri tanpa keluarganya (Seth-Smith, 2006). Oleh karena pendidikan dan perkembangan anak sangat terkait satu sama lain (Daniels \& Shumow, 2003), maka hal ini bisa kita lihat juga secara spesifik pada peranan guru. Mengacu pada Daniels dan Shumow (2003), peranan guru dalam perkembangan anak dapat dijelaskan menggunakan zona perkembangan proksimal (ZPD) yang dikemukakan oleh Vygotsky (1978), yaitu suatu proses dimana guru berperan dalam membimbing anak mulai dari mengenal sejauhmana perkembangan konseptual atau keterampilan mereka menuju pemahaman atau keterampilan yang lebih matang. Selain itu, peranan guru dalam mendukung perkembangan anak diungkapkan oleh Piaget (1964) bahwa untuk mendorong anak menjadi pemikir yang inventif, kreatif dan kritis maka guru perlu merancang lingkungan dan berinteraksi dengan anak (Daniels \& Shumow, 2003). Mengacu pada Seth-Smith (2006) peranan guru sebagai significant adults pada dunia anakanak sangat penting dalam mengembangkan kapasitas anak untuk meregulasi emosinya dan kesuksesannya dalam mengembangkan hubungan dengan teman sebaya.

Kesuksesan setiap program pendidikan tergantung pada kualitas dan sikap guru (Tyagi, 2016). Pada pendidikan inklusif, sikap guru memiliki pengaruh terhadap apakah lingkungan belajar bisa berjalan dengan kondusif atau tidak (Monsen, Ewing, \& Kwoka, 2014, dalam Ewing, Monsen, \& Kielblock, 2018) karena berdasarkan penelitian, inklusi merupakan masalah yang menantang bagi berbagai pihak, terutama guru (Sucuoğlu et al., 2013). Sikap guru sangat penting untuk keberhasilan program inklusi (Hastings \& Oakford, 2003). Berdasarkan teori yang mengungkapkan bahwa sikap seseorang dipengaruhi oleh reaksi kognitif, emosional, dan perilaku terhadap orang lain, maka jika dilihat dalam konteks ASD, sikap guru terhadap siswa dengan ASD dapat memiliki dampak luar biasa pada interaksi mereka dan pembelajaran yang diterapkan di kelas inklusif (Ozel Eren et al., 2017).

Sikap guru sangat bervariasi terhadap anak-anak dan remaja berkebutuhan khusus inklusi (Ewing et al., 2018). Variasi sikap tersebut dapat berupa sikap yang positif maupun negatif. Prediktor yang penting bagi keberhasilan pendidikan anak berkebutuhan khusus, termasuk anak dengan ASD adalah sikap guru yang positif (Robertson, Chamberlain, \& Kasari, 2003; Stanovich \& Jordan, 1998 dalam (Rodríguez, Saldaña, \& Moreno, 2012). Guru yang bersikap positif terhadap pendidikan inklusif akan secara alami menerapkan strategi instruksional yang efektif di kelas reguler dan akan menyesuaikan kurikulum dan materi saat di kelas inklusif (Campbell, Gilmore, \& Cuskelly, 2003 dalam Sucuoğlu et al., 2013). Sebaliknya, harapan yang lebih rendah terhadap pencapaian dan status sosial serta perilaku yang tidak sesuai terhadap siswa berkebutuhan khusus dapat muncul jika guru bersikap negatif (Larrivee, 1985; Larrivee \& Horne, 1991 dalam Sucuoğlu et al., 2013). Sikap negatif 
mengarah pada berkurangnya harapan dan kesempatan belajar bagi anak (Idol, 2006; Shade \& Stewart, 2001 dalam Sucuoğlu et al., 2013). Hal yang sama dikemukakan oleh Bhargava (2005 dalam Tyagi, 2016) bahwa salah satu yang menyebabkan munculnya kesulitan dalam pendidikan inklusif adalah sikap guru yang kurang sesuai.

Sikap (attitudes) adalah "a predisposition to respond to a particular object in a generally favorable or unfavorable way" (Ajzen, 1982 dalam DeLamater, Myers, \& Collet, 2015). Cara seseorang mempersepsi dan berespon terhadap dunia dipengaruhi oleh sikapnya (Allport, 1935; Thomas \& Znaniecki, 1918 dalam DeLamater et al., 2015). Berdasarkan DeLamater et al. (2015), terdapat tiga komponen sikap, yaitu: (1) beliefs atau cognition, serangkaian struktur kognisi atau pengetahuan yang berhubungan dengan objek (2) evaluation atau affective, terkait bagaimana perasaan seseorang terhadap suatu objek. Komponen ini memiliki dua arah (positif atau negatif) dan intensitas (dari sangat lemah hingga sangat kuat) (3) behavioral predisposition, predisposisi untuk berespon atau kecenderungan perilaku terhadap objek. Jika dikaitkan dengan ASD, maka sikap guru pada ketiga komponennya adalah pengetahuan guru tentang ASD (kognitif), perasaan guru terhadap ASD (afektif), dan predisposisi guru untuk berespon terhadap ASD (konatif/perilaku).

Mengingat pentingnya peranan guru terhadap keberhasilan pendidikan anak dengan ASD, khususnya pada konteks pendidikan anak usia dini, maka penelitian ini bertujuan untuk mengkaji secara sistematis hasil-hasil studi ilmiah, baik kuantitatif maupun kualitatif mengenai sikap guru terhadap anak usia dini dengan ASD dan faktor yang memengaruhi sikap tersebut.

\section{METODOLOGI}

Metode yang digunakan dalam kajian literatur ini menggunakan tahapan kajian sistematis PRISMA 2009 (Moher Liberati, Tetzlaff, Altman, The PRISMA Group, 2009). Tahapan tersebut mencakup 1) identifikasi melalui alat pencarian elektronik; 2) screening judul dan abstrak dan mengeliminasi yang tidak sesuai; 3) menguji kelayakan dengan menganalisis full-text dan mengeliminasi yang tidak sesuai. Total 2 artikel yang diperoleh sesuai dengan tujuan penelitian.

Artikel yang digunakan dalam penelitian ini adalah artikel yang membahas mengenai sikap guru terhadap anak usia dini dengan ASD. Kategori guru yang termasuk dalam penelitian ini adalah guru yang sedang mengajar di sekolah (in-service teacher) maupun calon guru (pre-service teacher). Penelitian ini memfokuskan pada anak prasekolah (PAUD ataupun TK) dengan ASD. Dalam penelitian ini, definisi operasional sikap yang digunakan mengacu pada "a predisposition to respond to a particular object in a generally favorable or unfavorable way" (Ajzen, 1982 dalam DeLamater et al., 2015).

Strategi pencarian artikel yang relevan dilakukan melalui alat pencarian elektronik Taylor \& Francis Online, ProQuest, EBSCOhost, dan Science Direct dengan memfokuskan pada artikel yang diterbitkan dalam 10 tahun terakhir, yaitu antara bulan Oktober 2009 hingga Oktober 2019, dan berbahasa Inggris. Pada alat pencarian elektronik Taylor \& Francis Online, pencarian dibatasi pada artikel dengan filter "only show content I have full access to". Pada alat pencarian elektronik ProQuest dan EBCOhost, pencarian dibatasi pada artikel yang lengkap (full text) dan sudah melalui proses peer-review. Pada alat pencarian elektronik Science Direct, pencarian dibatasi pada research article. Sejumlah kata kunci digunakan untuk menemukan artikel yang relevan. Kata kunci yang digunakan adalah teacher's attitude atau attitudes of teacher yang dipadukan dengan kata kunci seperti Autism Spectrum Disorder, autism, early childhood, preschool, inclusive education, dan student. Perpaduan kata kunci tersebut digunakan untuk melihat relevansi judul dan abstrak artikel dengan penelitian yang dilakukan. 
Kata kunci pencarian pada alat pencarian elektronik Taylor \& Francis Online yaitu 1) 'teacher's attitude' AND 'early childhood' AND 'Autism Spectrum Disorder' dan 2) 'teacher's attitude' AND 'early childhood' AND 'autism'. Dari proses pertama, ditemukan 821 artikel. Dari proses kedua, peneliti menemukan 378 artikel. Pencarian melalui alat pencarian elektronik ProQuest dilakukan dengan menggunakan kata kunci 1) 'teacher's attitude' AND 'early childhood' AND 'Autism Spectrum Disorder' dan diperoleh 312 artikel. Pencarian melalui alat pencarian elektronik EBCOhost dilakukan dengan menggunakan kata kunci 1) 'attitudes of teacher' AND 'student' AND 'autism', diperoleh 35 artikel dan 2) 'teacher attitudes' AND 'preschool' AND 'autistic' diperoleh 4 artikel. Selain itu, pencarian juga dilakukan pada alat pencarian elektronik Science Direct dengan kata kunci 'teacher's attitude' AND 'early childhood' AND 'autism'dengan perolehan 250 artikel. Tujuan dilakukannya pencarian menggunakan alat pencarian elektronik yang berbeda adalah untuk mengumpulkan lebih banyak artikel penelitian. Meskipun terdapat pengulangan kata kunci yang sama pada alat pencarian elektronik yang berbeda, namun artikel yang dibutuhkan dapat diperoleh dari langkah ini. Jika kata kunci yang sama pada alat pencarian elektronik yang berbeda menghasilkan artikel yang sama dan artikel tersebut dapat digunakan sebagai sumber, maka akan dihitung salah satu saja dari satu alat pencarian. Proses seleksi artikel terdiri dari identifikasi, screening, dan pembacaan judul dan/atau abstrak artikel dari keempat alat pencarian elektronik.

Setelah membaca judul dan/atau abstrak artikel, dari 1720 artikel terdapat 2 artikel yang relevan dengan penelitian. Alasan eleminasi terhadap artikel tersebut seperti 1) kriteria partisipan penelitian yang tidak sesuai dengan konteks misalnya sikap guru terhadap siswa autis di primary school, secondary school ataupun sikap in-service teacher di prasekolah, primary school, dan secondary school pada anak berkebutuhan khusus tanpa menspesifikasi pada kasus ASD 2) sikap guru terhadap siswa berkebutuhan khusus secara umum. Gambar 1 berikut adalah alur proses seleksi untuk memeroleh artikel.

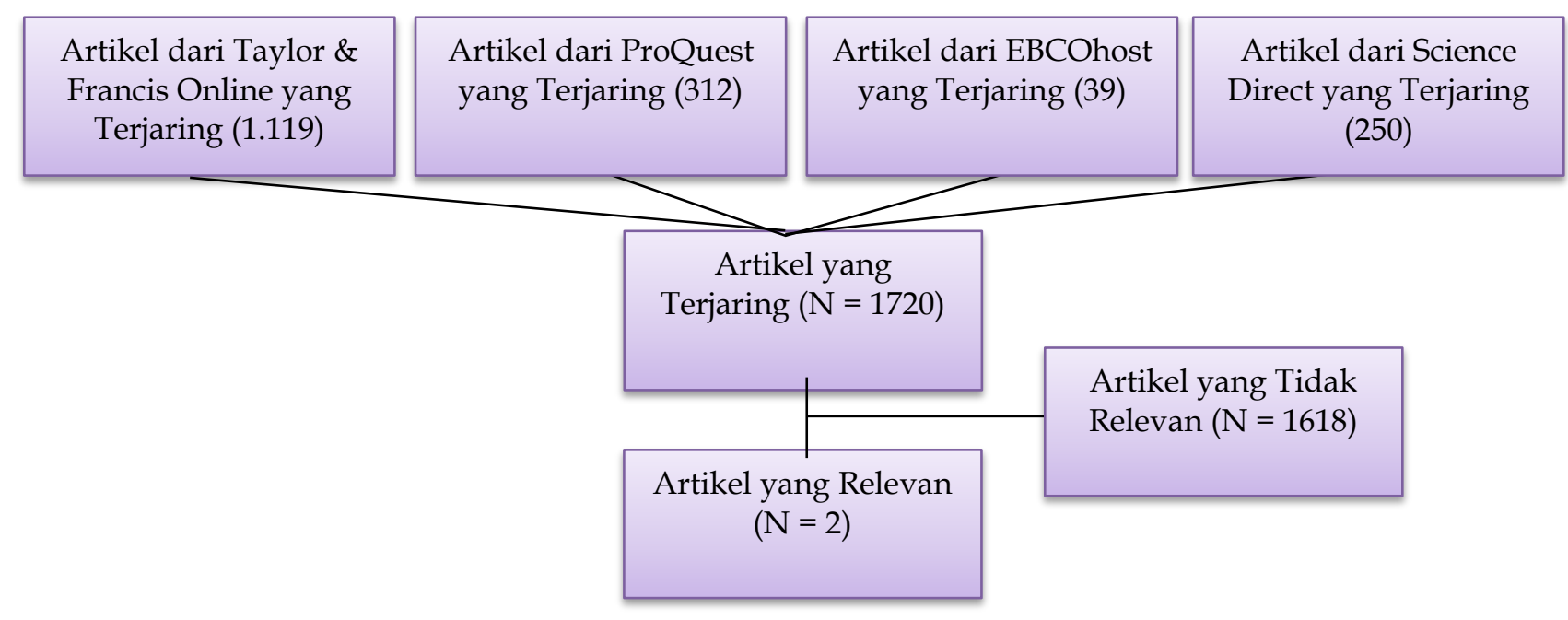

Gambar 1. Diagram alur proses seleksi artikel

\section{HASIL DAN PEMBAHASAN}

Berdasarkan pencarian artikel yang telah dilakukan melalui tahapan identifikasi, screening, hingga eliminasi pada empat alat pencarian elektronik, yaitu Taylor \& Francis Online, ProQuest, EBSCOhost, dan Science Direct maka diperoleh dua artikel yang relevan dan bisa diproses ke dalam tahap review. Kedua artikel tersebut masing-masing diperoleh dari alat pencarian elektronik Taylor \& Francis Online dan ProQuest. Berikut gambaran dari kedua penelitian tersebut yang dirangkum ke dalam Tabel 1. 
Karakteristik Partisipan Mengacu pada kedua artikel relevan yang diperoleh, dapat diketahui bahwa dari total 486 orang partisipan, mayoritas dari mereka adalah perempuan $(\mathrm{N}=482)$. Partisipan terdiri dari calon guru (pre-service teacher) (Barned, Knapp, \& NeuharthPritchett, 2011) dan guru (in-service teacher) prasekolah di kota Guangzhou dan Foshan, China (Liu, Li, Zheng, Zaroff, Hall, Li, \& Hao, 2016). Pre-service teacher yang terlibat merupakan mereka yang memiliki ketertarikan untuk bekerja dengan anak-anak, baik yang sudah terdaftar maupun yang ingin mendaftar pada program persiapan guru early childhood. Mereka adalah mahasiswa program sarjana jurusan psikologi pendidikan di Southeastern University dengan berbagai variasi angkatan. Pre-service teacher yang terlibat dalam penelitian Barned et al. (2011) belum pernah mengikuti pelatihan dalam mengajar anak ASD. Terdapat 8 dari 15 pre-service teacher tersebut memiliki pengalaman berinteraksi dengan anak ASD, di luar bidang pengajaran. Sedangkan in-service teacher yang terlibat pada penelitian sebagian besar pernah mengikuti pelatihan perkembangan anak usia dini secara formal (83\%), sebagian kecil pernah mengikuti pelatihan formal terkait pemberian instruksi terhadap anak berkebutuhan khusus $(16,3 \%)$, dan sekitar setengah dari jumlah partisipan memiliki pengalaman bekerja dengan anak berkebutuhan khusus (58,3 \%) (Liu et al., 2016).

Metode Pengambilan Data Kedua penelitian tersebut memiliki kesamaan dalam hal tipe penelitian kuantitatif, yaitu menggunakan kuesioener sebagai instrumennya. Penelitian Barned et al. (2011) menggunakan versi modifikasi dari Autism Inclusion Questionnaire (AIQ) yang dikembangkan oleh Segall (2008)dengan tujuan mengukur pengalaman, sikap, dan pengetahuan tentang anak ASD. Selain kuesioner, penelitian Barned et al. (2011) ini memiliki tambahan instrumen berupa wawancara mendalam (tipe penelitian kualitatif) terhadap 4 orang yang secara sukarela ingin membagi pengalamannya. Wawancara ini dilakukan seminggu setelah survei dilakukan dan berlangsung sekitar 30 menit. Fokus dari wawancara yang dilakukan adalah ingin menilai 1) konsistensi dan alasan dari respon yang diberikan oleh partisipan saat mengisi kuesioner 2) sikap dan nilai yang dimiliki partisipan terhadap inklusi dengan siswa ASD. Penelitian Liu et al. (2016) menggunakan kuesioner yang telah digunakan oleh beberapa penelitian sebelumnya yang kemudian disesuaikan dengan konteks budaya Cina. Aitem kuesioner yang digunakan berupa skala Likert yang terdiri dari lima pilihan respon dari 1 ('sangat tidak setuju') hingga 5 ('sangat setuju') untuk mengukur sikap in-service teacher terhadap kebutuhan anak ASD. Di bawah ini terdapat tabel 1 yang berisi gambaran hasil penelitian yang terseleksi.

\section{Tabel 1. Gambaran Penelitian yang Terseleksi}

\begin{tabular}{|c|c|c|c|c|c|c|c|}
\hline No. & Artikel & $\begin{array}{c}\text { Tipe } \\
\text { Penelitian }\end{array}$ & $\begin{array}{c}\text { Metode } \\
\text { Pengambilan } \\
\text { Data }\end{array}$ & & $\begin{array}{c}\text { Karakteristik Partisipan } \\
\text { Pelatihan/Pengala- } \\
\text { man Mengajar anak } \\
\text { usia dini / anak } \\
\text { berkebutuhan } \\
\text { khusus/ASD }\end{array}$ & Gender & $\begin{array}{c}\text { Total } \\
\text { (n) }\end{array}$ \\
\hline 1 & $\begin{array}{l}\text { Barned, } \\
\text { Knapp, } \\
\text { dan } \\
\text { Neuharth } \\
\text {-Pritchett } \\
\text { (2011) }\end{array}$ & $\begin{array}{l}\text { Kuantitatif } \\
\text { dan } \\
\text { Kualitatif }\end{array}$ & $\begin{array}{l}\text { Kuesioner (15 } \\
\text { orang) dan } \\
\text { wawancara } \\
\text { mendalam (4 } \\
\text { orang) }\end{array}$ & $\begin{array}{l}\text { Early } \\
\text { Childhood } \\
\text { Preservice } \\
\text { Teacher di } \\
\text { Southeastern } \\
\text { University }\end{array}$ & Tidak & $\begin{array}{c}\text { Perem- } \\
\text { puan }\end{array}$ & 15 \\
\hline 2 & $\begin{array}{l}\text { Liu, Li, } \\
\text { Zheng, } \\
\text { Zaroff, } \\
\text { Hall, Li, } \\
\text { dan Hao } \\
\text { (2016) }\end{array}$ & Kuantitatif & $\begin{array}{l}\text { Pengisian } \\
\text { kuesioner }\end{array}$ & $\begin{array}{l}\text { Guru } \\
\text { prasekolah } \\
\text { di kota } \\
\text { Guangzhou } \\
\text { dan Foshan, } \\
\text { China }\end{array}$ & Ya & $\begin{array}{l}\text { Laki-laki } \\
\text { (4 orang) } \\
\text { dan } \\
\text { perem- } \\
\text { puan } \\
\text { (467 } \\
\text { orang) }\end{array}$ & 471 \\
\hline \multicolumn{7}{|c|}{ Total partisipan dari 2 penelitian } & $\begin{array}{c}486 \\
\text { orang }\end{array}$ \\
\hline
\end{tabular}


Hasil penelitian yang dilakukan terhadap pre-service teacher oleh Barned et al. (2011) dapat dilihat secara kuantitatif maupun kualitatif. Secara kuantitatif sikap partisipan penelitian menunjukkan bahwa mayoritas pre-service teacher menyetujui bahwa anak ASD seharusnya dimasukkan ke dalam sistem pendidikan umum (93,3\%). Meskipun demikian, setengah dari mereka menyatakan beberapa kekhawatiran bahwa tidak semua anak dengan ASD harus dimasukkan ke dalam sistem tersebut (53,3\%). Pre-service teacher melihat beberapa manfaat inklusi bagi anak ASD maupun anak yang tidak berkebutuhan khusus. Bagi anak ASD manfaat inklusi yaitu untuk meningkatkan pengalaman belajar mereka $(86,7 \%)$ sedangkan anak-anak yang tidak berkebutuhan khusus disetujui oleh semua partisipan juga dapat memperoleh manfaat dari berinteraksi dengan anak-anak berkebutuhan khusus (100\%). Mayoritas partisipan menyetujui bahwa guru pendidikan umum yang bagus tetap bisa membantu siswa dengan ASD (80\%). Partisipan penelitian juga disurvei mengenai faktor dari karakteristik anak ASD yang bisa memiliki peranan penting terhadap keberhasilan inklusi. Menurut mereka, faktor-faktor itu adalah kemampuan akademik, tingkat gangguan dari kebutuhan khusus yang dialami, dan kepribadian anak.

Secara kualitatif, keempat partisipan yang mengikuti wawancara setuju jika anak ASD dimasukkan ke dalam kelas inklusif. Mereka juga mendukung bahwa inklusi memiliki manfaat bagi kedua pihak, yaitu siswa ASD dan siswa yang tidak memiliki kebutuhan khusus. Akan tetapi, mereka cenderung menyatakan bahwa kesuksesan inklusi utamanya dapat diperoleh jika masalah atau gangguan tingkah laku yang muncul dari anak ASD yang ada di kelas inklusi adalah sedikit. Dengan demikian, pada umumnya dapat dilihat baik secara kuantitatif maupun kualitatif bahwa sikap yang ditunjukkan oleh per-service teacher positif terhadap inklusi dimana di dalamnya terdiri dari anak ASD.

Dari sisi penelitian in-service teacher oleh Liu et al. (2016), guru memiliki keinginan yang kuat untuk menangani anak ASD namun bersikap rata-rata netral atau sedikit setuju mengenai sejauhmana pelatihan yang pernah mereka ikuti dan kemampuan mereka dapat menunjang keberhasilannya dalam mendidik ASD. Artinya, keinginan kuat guru dalam menangani anak ASD tidak sebanding dengan keyakinan bahwa mereka mampu/berhasil dalam melakukannya meskipun mereka pernah mengikuti pelatihan. Selain itu, terkait kemungkinan anak ASD ditempatkan di lingkungan sekolah inklusif, persentase pendapat guru cenderung netral. Jika dilihat dari minat dan bagaimana mereka mempersepsikan kemampuan mereka dalam menangani anak ASD diperoleh hasil sebagai berikut (diambil aitem yang bukan terkait dengan persepsi terhadap pelatihan) 1) partisipan merasa siap untuk menangani anak-anak ASD (27\% sangat setuju, $18 \%$ setuju) 2) partisipan melihat perlunya melakukan perubahan di kelas untuk mengakomodasi ASD (48\% sangat setuju, $20 \%$ setuju) 3) partisipan ingin membuat perbedaan dalam pendidikan anak-anak ASD (48\% sangat setuju, 22\% setuju) 4) partisipan merasa dapat membuat perbedaan dalam pendidikan anak-anak ASD (16\% sangat setuju, $15 \%$ setuju). Berdasarkan hasil ini, dapat diketahui bahwa umumnya pendapat partisipan tergolong netral hingga sedikit setuju dalam mempersepsikan kesiapan mereka dalam mendidik anak ASD di kelas.

Dari penelitian Barned et al. (2011) dan Liu et al. (2016) diperoleh tiga persamaan. Pertama, kedua penelitian melihat sejauhmana pengetahuan partisipan terhadap ASD. Hasilnya, pre-service teacher maupun in-service teacher memiliki pengetahuan yang kurang serta memiliki kesalahpahaman dasar tentang ASD dan kebutuhan anak-anak dengan ASD di ruang kelas inklusif. Kedua, melihat keterbatasan pengetahuan tersebut maka kedua penelitian menyarankan untuk dilakukannya program pelatihan. Ketiga, masing-masing partisipan memiliki keinginan untuk memelajari secara lebih baik keterampilan yang dibutuhkan untuk memaksimalkan pengalaman dalam mengajar anak ASD.

Dari kedua penelitian ini dapat dilihat bahwa terdapat perbedaan sikap yang ditunjukkan oleh masing-masing guru. Pre-service teacher menunjukkan sikap yang positif Barned et al. (2011) sedangkan in-service teacher menampilkan sikap yang netral dan sedikit setuju (Liu et al., 2016). Perbedaan lainnya adalah pre-service teacher setuju jika anak ASD 
dimasukkan ke dalam lingkungan inklusif sedangkan in-service teacher cenderung netral. Penelitian Liu et al. (2016) yang menunjukkan sikap netral atau sedikit setuju walaupun sudah pernah mengikuti pelatihan perlu diperhatikan. Sebagian besar partisipan tersebut mengikuti pelatihan mengenai perkembangan anak usia dini $(83 \%)$ sedangkan lebih dari setengah guru yang memiliki pengalaman mengajar dengan ABK $(58,3 \%)$ hanya sedikit $(16,3 \%)$ dari mereka yang mengikuti pelatihan mengenai ABK. Hasil penelitian Liu et al. (2016) ini tidak sesuai dengan hasil penelitian yang menunjukkan bahwa pengalaman pelatihan mengenai pendidikan inklusif atau ABK pada guru prasekolah inklusif berdampak signifikan terhadap aspek sikap (kognitif maupun afektif) guru (Rumalutur \& Kurniawati, 2019). Artinya, dengan adanya pelatihan maka sikap guru akan lebih positif.

\section{Batasan Penelitian dan Saran}

Kedua penelitian yang relevan dengan tujuan kajian literatur sistematis ini belum bisa digeneralisasi karena beberapa hal. Pertama, jumlah artikel yang digunakan pada kajian ini terbatas. Kedua, instrumen yang digunakan oleh kedua penelitian adalah kuesioner sehingga hasil yang diperoleh dari partisipan baru mengukur komponen kognitif dari sikap dan memungkinkan kecenderungan social desirability yang tinggi. Salah satu penelitian, yaitu oleh Barned et al. (2011) memang menggunakan tambahan instrumen yaitu melalui wawancara namun partisipannya sedikit sehingga informasi yang diperoleh belum komprehensif. Ketiga, kedua penelitian dilakukan di negara dan budaya yang berbeda, yaitu China dan Amerika. Meskipun demikian, faktor tersebut masih belum mampu dijadikan sebagai landasan kesimpulan terkait bagaimana sikap guru terhadap anak usia dini dengan ASD secara lebih luas dari berbagai negara dan latar belakang budaya yang beragam. Keempat, pada penelitian oleh Liu et al. (2016) pada in-service teacher partisipan pernah mengikuti pelatihan namun justru menampilkan sikap yang netral dan sedikit setuju.

Mengacu pada batasan di atas, maka penelitian disarankan untuk dilakukan terhadap guru-guru PAUD inklusif di Indonesia untuk memperluas gambaran dalam berbagai konteks budaya dan negara, serta memfokuskan penelitian sikap guru yang bukan merupakan dampak hasil pelatihan tertentu. Terlepas dari keterbatasan yang dimilikinya, kajian literatur ini telah memberikan gambaran sekilas baik secara kuantitatif maupun kualitatif terkait sikap guru yang terdiri dari pre-service teacher maupun in-service teacher terhadap anak usia dini dengan ASD pada konteks pendidikan inklusif.

\section{SIMPULAN}

Terdapat perbedaan sikap yang ditampilkan oleh masing-masing partisipan. Pre-service teacher yang merupakan calon guru menunjukkan sikap yang positif sedangkan in-service teacher atau guru yang mengajar di prasekolah menampilkan sikap yang netral dan sedikit setuju mengenai anak usia dini dengan ASD dalam konteks pendidikan inklusif. Hal menarik ditemukan dalam penelitian Barned et al. (2011) dan Liu et al. (2016) mengenai persamaan dalam tiga hal. Pertama, kedua penelitian melihat sejauhmana pengetahuan partisipan terhadap ASD. Hasilnya, meskipun masing-masing partisipan ini memiliki pengalaman yang berbeda, yaitu ada yang belum pernah mengajar dan ada yang pernah mengajar anak ASD, namun mereka memiliki pengetahuan yang kurang serta masih adanya kesalahpahaman mengenai ASD dan kebutuhannya saat dimasukkan ke dalam kelas inklusif. Kedua, melihat keterbatasan pengetahuan tersebut maka kedua penelitian menyarankan untuk dilakukannya program pelatihan. Ketiga, masing-masing partisipan ingin memelajari secara lebih baik keterampilan yang dibutuhkan untuk memaksimalkan pengalaman dalam mengajar anak ASD. Hasil dari kajian literatur ini dapat dipertimbangkan untuk guru-guru PAUD Inklusif di Indonesia supaya mereka memiliki keterampilan dalam mengajar anak ASD. Selain itu, pentingnya mereka memiliki pengetahuan yang mumpuni tentang ASD. Melalui keterampilan dan pengetahuan yang 
memadai tentang anak ASD maka sikap guru dalam mengajar akan berkembang ke arah positif.

\section{UCAPAN TERIMAKASIH}

Terimakasih peneliti ucapkan kepada pihak-pihak terkait dalam penelitian dan publikasi artikel ini terutama kepada orangtua, dan pembimbing.

\section{DAFTAR PUSTAKA}

Barned, N. E., Knapp, N. F., \& Neuharth-Pritchett, S. (2011). Knowledge and attitudes of early childhood preservice teachers regarding the inclusion of children with autism spectrum disorder. Journal of Early Childhood Teacher Education, 32(4), 302-321. https:/ / doi.org/10.1080/10901027.2011.622235

Brooks, J. B. (2013). The Process of Parenting (9th ed.). New York: McGraw-Hill.

Copeland, J. N. (2018). What is autism spectrum disorder?

Daniels, D. H., \& Shumow, L. (2003). Child development and classroom teaching: A review of the literature and implications for educating teachers. Journal of Applied Developmental Psychology. https://doi.org/10.1016/S0193-3973(02)00139-9

DeLamater, J. D., Myers, D. J., \& Collett, J. L. (2015). Attitudes. In Social Psychology (8th ed.). Westview Press.

Diamond, K. E., \& Hestenes, L. L. (1996). Preschool children's conceptions of disabilities: The salience of disability in children's ideas about others. Topics in Early Childhood Special Education. https://doi.org/10.1177/027112149601600406

Ewing, D. L., Monsen, J. J., \& Kielblock, S. (2018). Teachers' attitudes towards inclusive education: A critical review of published questionnaires. Educational Psychology in Practice. https:/ / doi.org/10.1080/02667363.2017.1417822

Fakolade, O. A., Adeniyi, S. O., \& Tella, A. (2009). Attitude of teachers towards the inclusion of special needs children in general education classroom: The case of teachers in some selected schools in Nigeria. International Electronic Journal of Elementary Education, 1(3), 155-169.

Hastings, R. P., \& Oakford, S. (2003). Student teachers' attitudes towards the inclusion of children with special needs. Educational Psychology, 23(1), 87-94. https://doi.org/10.1080/01443410303223

Liu, Y., Li, J., Zheng, Q., Zaroff, C. M., Hall, B. J., Li, X., \& Hao, Y. (2016). Knowledge, attitudes, and perceptions of autism spectrum disorder in a stratified sampling of preschool teachers in China. BMC Psychiatry, 16(142), 1-12. https://doi.org/10.1186/s12888-016-0845-2

Mash, E. J., \& Wolfe, D. A. (2016). Abnormal Child Psychology (6th ed.). Boston: Cengage Learning.

Moher, D., Liberati, A., Tetzlaff, J., Altman, D. G., Altman, D., Antes, G., ... Tugwell, P. (2009). Preferred reporting items for systematic reviews and meta-analyses: The PRISMA statement. PLoS Medicine. https://doi.org/10.1371/journal.pmed.1000097

Mullin, A. P., Gokhale, A., Moreno-De-Luca, A., Sanyal, S., Waddington, J. L., \& Faundez, V. (2013). Neurodevelopmental disorders: Mechanisms and boundary definitions from genomes, interactomes and proteomes. Translational Psychiatry, pp. 1-6. https://doi.org/10.1038/tp.2013.108

Ozel Eren, E., Sakalli Gumus, S., Ganesan, M. Z., Megat Daud, A. K., Darusalam, G. Bin, \& Siraj, S. (2017). Teachers' attitudes investigated towards students with Autism Spectrum Disorder. Turkish Online Journal of Educational Technology.

Papalia, D. E., \& Martorell, G. (2014). Experience Human Development (13th ed.). New York: McGraw-Hill.

Rodríguez, I. R., Saldaña, D., \& Moreno, F. J. (2012). Support, inclusion, and special education teachers' attitudes toward the education of students with Autism Spectrum 
Disorders. Autism Research and Treatment, 2012. https:/ / doi.org/10.1155/2012/259468

Rumalutur, N. A., \& Kurniawati, F. (2019). The attitudes of in-service and pre-service teachers toward inclusive education. 2nd International Conference on Intervention and Applied Psychology (ICIAP 2018). https:// doi.org/10.2991/iciap-18.2019.53

Santrock, J. W. (2012). Educational Psychology (5th ed.). New York: McGraw Hill.

Segall, M. J. (2008). Inclusion of students with autism spectrum disorder: Educator experience, knowledge, and attitudes. University of Georgia.

Seth-Smith, F. (2006). How do teachers influence children's emotional development?

Sharma, S. R., Gonda, X., \& Tarazi, F. I. (2018). Autism Spectrum Disorder: Classification, diagnosis and therapy. Pharmacology and Therapeutics, pp. 91-104. https:// doi.org/10.1016/j.pharmthera.2018.05.007

Stahmer, A. C., Akshoomoff, N., \& Cunningham, A. B. (2011). Inclusion for toddlers with Autism Spectrum Disorders: The first ten years of a community program. Autism. https:// doi.org/10.1177/1362361310392253

Sucuoğlu, B., Bakkaloğlu, H., Karasu, F. I., Demir, Ş., \& Akalin, S. (2013). Inclusive preschool teachers: Their attitudes and knowledge about inclusion. International Journal of Early Childhood Special Education, 5(2), 107-128. https:// doi.org/10.20489/intjecse.107929

Tichá, R., Abery, B. H., Johnstone, C., Poghosyan, A., \& Hunt, P. F. (Eds.). (2018). Inclusive Education Strategies: A Textbook. Minneapolis: University of Minnesota; Yerevan, Armenia: UNICEF Armenia \& Armenian State Pedagogical University.

Tyagi, G. (2016). Role of teacher in inclusive education. International Journal of Education and Applied Research, 6(1), 115-116.

WHO-UNICEF. (2012). Early childhood development and disability: A discussion paper. Geneva. 